A New Pleistocene Deer-Mouse from Santa Rosa Island, California Author(s): Robert W. Wilson

Source: Journal of Mammalogy, Vol. 17, No. 4 (Nov., 1936), pp. 408-410

Published by: American Society of Mammalogists

Stable URL: https://www.jstor.org/stable/1374408

Accessed: 19-02-2020 00:17 UTC

JSTOR is a not-for-profit service that helps scholars, researchers, and students discover, use, and build upon a wide range of content in a trusted digital archive. We use information technology and tools to increase productivity and facilitate new forms of scholarship. For more information about JSTOR, please contact support@jstor.org.

Your use of the JSTOR archive indicates your acceptance of the Terms \& Conditions of Use, available at https://about.jstor.org/terms

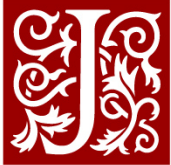

American Society of Mammalogists is collaborating with JSTOR to digitize, preserve and extend access to Journal of Mammalogy 


\section{A NEW PLEISTOCENE DEER-MOUSE FROM SANTA ROSA ISLAND, CALIFORNIA}

\section{By ROBERT W. Wilson}

Subsequent to 1928, collections of fossil vertebrate remains from Santa Rosa Island, California, have been made by the California Institute of Technology. These have included a considerable number of fragmentary remains of elephants (Stock, C., and E. L. Furlong, Science, vol. 68, pp. 140-141, 1928; Stock, C., Sci. Monthly, vol. 41, pp. 205-214, 1935). Material representing this mammal has been known from the island for more than 60 years, but, curiously, no other sort of fossil mammal was discovered in this locality until the fall of 1934, when there was collected in Pleistocene deposits a rodent specimen of the genus Peromyscus, quite distinct from the species inhabiting the area at the present time.

\section{Peromyscus nesodytes, new species}

Locality and Geological Horizon-Locality 106, Calif. Inst. Tech., Coll. Vert. Pal., Santa Rosa Island, Santa Barbara County, California; Pleistocene. Pal.

Type Specimen-A right ramus with $\mathrm{M}_{1}-\mathrm{M}_{3}$, no. 1780, Calif. Inst. Tech. Coll. Vert.

Specific Characters-Partially bipartite antero-median cusp in $\mathrm{M}_{1}$. Antero-internal valley in $\mathrm{M}_{1} \mathrm{~V}$-shaped. No accessory tubercles on cheek-teeth. Size very large, slightly larger than Peromyscus antiquus. Length of tooth-row, $\mathrm{M}_{1}-\mathrm{M}_{3}, 5.9 \mathrm{~mm}$.

Remarks.-The outstanding character of $P$. nesodytes is its large size, which is greater than any living species of Peromyscus native to the United States; it appears to be exceeded in size only by members of the subgenus Megadontomys of southern Mexico and Central America.

There exists in the cheek-teeth of Peromyscus a relatively large amount of individual variation. Hence, the following discussion is subject to some uncertainty, inasmuch as $P$. nesodytes is known only from a single specimen.

The cheek-teeth of $P$. nesodytes are comparable in size-relative to each otherand in shape to those of living members of the genus. Absence of supplementary tubercles in the cheek-teeth and the large size of $P$. nesodytes suggest relationship with the subgenus Haplomylomys, and especially with P. californicus. The fossil species not only exceeds the latter in size, however, but the antero-median cusp of $M_{1}$ is separated from the antero-internal cusp by a pronounced $\mathrm{V}$-shaped valley. In $P$. californicus the valley is extremely compressed and parallel-sided, and the anterior and posterior enamel borders with wear show a tendency to become united at the inner margin of the tooth. When the latter condition exists, the outer tip of the valley commonly assumes a lake-like appearance.

A number of specimens of $P$. californicus were studied and the last-mentioned character apparently is significant for both $P$. c. californicus and $P$. c. insignis. In a recent paper by Grinnell and Orr (Jour. Mamm., vol. 15, pp. 210-220, 1934), P. californicus is differentiated into 5 races instead of the 2 heretofore recognized. The specimens studied in the present connection apparently do not represent all 5 of these races but are from sufficiently varied localities to indicate that the character under discussion is not one of merely subspecific value. Reference to $P$. c. californicus in this paper is not to the race as restricted by Grinnell and Orr, but to the subspecies recognized by earlier authors. 
An additional character which may help to distinguish the fossil species from at least some races of $P$. californicus is the partially divided antero-median cusp in $M_{1}$. In $P$. nesodytes the division is quite clearly marked and is distinct enough to give some indication of its presence even in worn teeth. In $P$. c. californicus, as represented by the series of specimens of this subspecies examined during the course of the present study, it is generally but not invariably absent. In $P$. $c$. insignis the divided anteromedian cusp sometimes is present.

Peromyscus eremicus is another member of the subgenus Haplomylomys with which comparison might be made. In several of its characters it resembles the fossil species. The inner borders of the antero-internal valley are usually separate as in the Pleistocene type, although the re-entrant $\mathrm{V}$ is commonly narrower and more parallel-sided. $P . e$. eremicus has a bicuspate antero-median cusp in $\mathrm{M}_{1}$ as in $P$. nesodytes. The species is much smaller than the new type, however. On the other hand, there are cases of insular rodents that are larger than related mainland forms, and it is not outside the bounds of possibility that the Santa Rosa Island form is an extremely large member of the eremicus group. With only the present material available this hypothesis can be neither

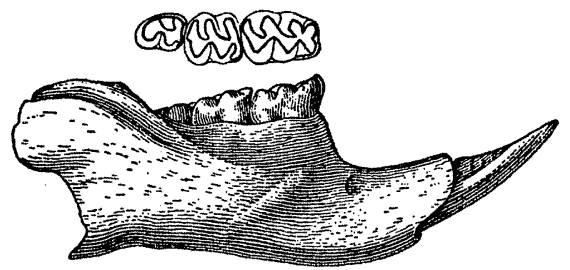

FIg. 1. Type specimen of Peromyscus nesodytes, right ramus with lower dentition, no. 1780 Calif. Inst. Tech. Vert. Pal. Coll.; lateral view and occlusal pattern of teeth; approximately $\times 3$.

proved nor disproved. Doctor E. Raymond Hall has suggested to the author that a species identical with or similar to $P$. nesodytes may now be living on Santa Rosa Island, but has not been recorded in the Recent fauna.

The principal character distinguishing Haplomylomys from other subgenera of Peromyscus is the absence of supplementary tubercles in the cheek-teeth. This feature is not absolute and certain species of the subgenus Peromyscus approach Haplomylomys in this respect. This is especially true of the lower cheek-teeth. Peromyscus (Peromyscus) maniculatus is a species in which the intermediate tubercles of the lower dentition are rather poorly developed, at least in some races, and individual specimens may have these cuspules practically nonexistent. The insular race $P$. maniculatus streatori inhabits Santa Rosa Island at the present time. This form is much smaller than $P$. nesodytes and moreover does not possess the divided antero-median cusp on $M_{1}$. $\quad P . m$. streatori resembles the fossil form, however, in shape of the antero-internal valley in $\mathbf{M}_{1}$.

Representatives of the subgenus Megadontomys surpass $P$. nesodytes in size. The subgenus is characterized, however, by very prominent accessory cusps, even in the lower molars, and thus is readily distinguished from the island form.

Previously known extinct types of Peromyscus appear to be farther removed from $P$. nesodytes than are some of the living forms. P. antiquus (Kellogg, L., Univ. Calif. Publ., Bull. Dept. Geol., vol. 5, pp. 432-433, 1910) from the Thousand Creek beds of northwestern Nevada agrees fairly closely with $P$. nesodytes in size but has a large $\mathbf{M}_{3}$, whereas in our type and in Recent species $\mathrm{M}_{3}$ is more reduced. In addition, $P$. antiquus 
has a strong antero-external ridge in $\mathrm{M}_{3}$. In $P$. nesodytes the stage of wear makes it difficult to determine the development of this character, but presumably the ridge is rather weak.

Contribution no. 183, Balch Graduate School of the Geological Sciences, California Institute of Technology, Pasadena, California.

\section{GENERAL NOTES}

\section{AN OPOSSUM DIES OF COLD AND HUNGER}

An opossum, found in a snow drift near Ann Arbor, Michigan, on March 8, 1936, by A. S. Hazzard and examined by myself, is believed to have died of cold and hunger. Hazzard discovered the dead animal in a hedge-row at his home, 4 miles east of Ann Arbor, when it was revealed by the melting of the drifted snow. It may have died any time during the 6 or 8 weeks of cold weather preceding the thaw. During that time zero or near-zero weather prevailed, and the ground had an unusually thick covering of ice and snow.

An examination of the carcass revealed no injuries nor evidence of disease, but the animal was very lean. The digestive tract was empty except for a small amount of debris in the stomach. This consisted of fragments of dead sticks, weeds and grass and a quantity of gritty material, apparently dirt, that the opossum had eaten, evidently in a desperate attempt to ward off starvation. Undoubtedly many small mammals suffered during the cold weather, but this is the only record that I have of one succumbing to it.-W. Frank BlaIr, Museum of Zoology, University of Michigan, Ann Arbor, Michigan.

\section{WINTER DAYTIME DENS OF OPOSSUMS}

During the months of November and December, 1925, in Webster County, Mississippi, the writer took 36 opossums from self-chosen day-time dens. Every individual was removed from its den during daylight hours, and most of the specimens, except those taken several feet above the ground, were located by a dog. The following table shows the occurrence of opossums by den types:

\begin{tabular}{|c|c|c|c|c|}
\hline \multirow{2}{*}{ OPOSSUMB TAKEN IN: } & \multicolumn{3}{|c|}{ NUMBER } & \multirow{2}{*}{$\begin{array}{l}\text { PHR CENT } \\
\text { OF TOTAL }\end{array}$} \\
\hline & Male & Female & Total & \\
\hline Trees (standing, green or dead). & 4 & 2 & 6 & 16.7 \\
\hline Logs (horizontal, on or above ground)... & 5 & 6 & 11 & 30.5 \\
\hline Stumps (hardwood, old and decayed). & 1 & 2 & 3 & 8.3 \\
\hline Debris (slashings and brush on ground). & 2 & 1 & 3 & 8.3 \\
\hline Vine-brush tangles (at swamp borders).. & 2 & 0 & 2 & 5.6 \\
\hline Leaf dens (squirrel? dens in branch crotches). & 2 & 0 & 2 & 5.6 \\
\hline Underground dens (cavities in soil).......... & 3 & 4 & 7 & 19.4 \\
\hline Attic of abandoned house (third floor). & 1 & 1 & 2 & 5.6 \\
\hline Totals. & 20 & 16 & 36 & 100.0 \\
\hline
\end{tabular}

In 3 instances 2 opossums were taken in single dens, but no den yielded more than 2 individuals. The sexes never were mixed, as 2 dens produced 2 females each and the 